\title{
Agroecology and Climate Change Adaptation: Farmers' Experiences in the South African Lowveld
}

\author{
Cryton Zazu and Anri Manderson
}

\section{Contents}

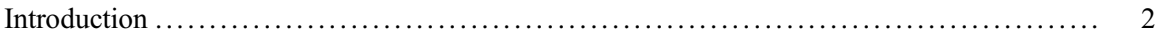

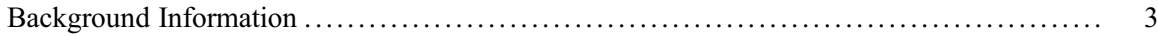

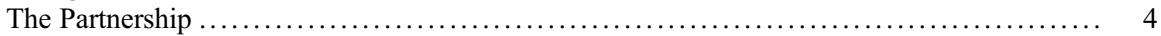

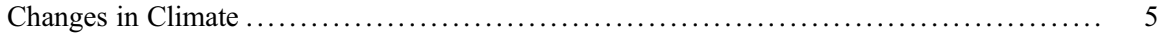

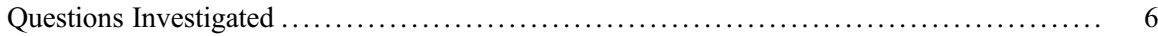

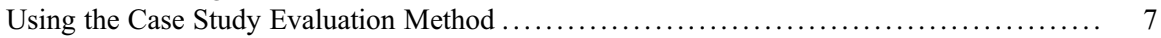

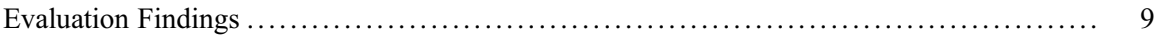

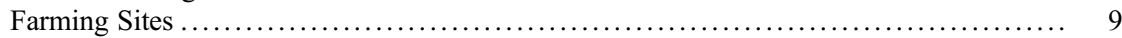

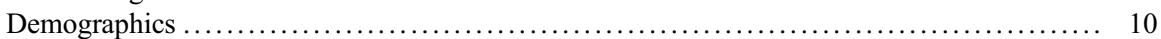

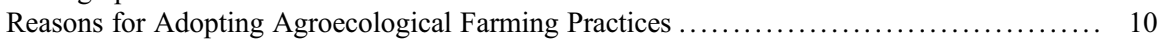

The Connection Between Agroecology and Climate Change .......................... 13

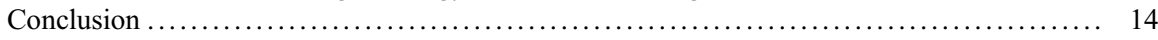

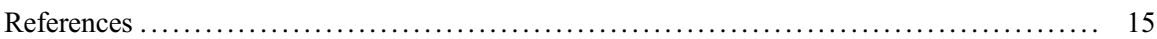

\begin{abstract}
Motivated by interest to increase the resilience of smallholder farmers to adapt to climate change through uptake of agroecology, two community development organizations commissioned a project evaluation upon which this book chapter is written. The chapter discusses how smallholder farmers were experiencing implementing agroecology, trying to understand the reasons for adopting such an
\end{abstract}

This chapter was previously published non-open access with exclusive rights reserved by the Publisher. It has been changed retrospectively to open access under a CC BY 4.0 license and the copyright holder is "The Author(s)". For further details, please see the license information at the end of the chapter.

C. Zazu $(\bowtie)$

Environmental Learning Research Centre, Rhodes University, Grahamstown, South Africa

A. Manderson

Hoedspruit Hub, Hoedspruit, South Africa

e-mail: anri@hoedspruithub.com 
approach to farming. The chapter also explores and problematizes the relationship between trends in adoption of agroecology and the smallholder farmers' awareness of climate change and adaptation. The chapter confirms that agronomic and income generation are the key reasons for adoption of agroecology. Most of the farmers reminisced about how their crop yields had declined and soils no longer producing enough to feed the family. Other motivating factors for uptake of agroecology included lack of employment, limited income sources, access to health organic foods, and medicinal value of herbs grown. The chapter further concluded that the correlation between adoption of agroecology and farmers' awareness of it as a climate change adaptation measure is generally weak. Smallholder farmers adopted agroecology more for responding to issues of food security, than any conscious desire to adapt to climate change. Implications of this observation is that practitioners working with smallholder farmers need to rethink their approaches and design of interventions to integrate climate change education and learning, so that strong connections between the agroecological practices promoted and adaptation to climate change are made. Such an approach has potential to improve the sustainability and value of the agroecological practices adopted.

\section{Keywords}

Agroecology $\cdot$ Permaculture $\cdot$ Climate change $\cdot$ Smallholder farmer $\cdot$ Adaptation $\cdot$ Mitigation

\section{Introduction}

Social development organizations have noticed an increase in agroecological activity among smallholder farmers in the South African lowveld in the last 2 years, including in the districts of the Kruger to Canyons Biosphere Region. Agroecology has also become the point of convergence for a network of institutions based in the biosphere and focusing on a range of environmental, climate change, and social concerns. These institutions included the Hoedspruit Hub, Association for Water and Rural Development (AWARD) Mahlatini, Ukuvuna, Kruger to Canyons Biosphere, CHoiCE Trust, Hlokomela, SANParks, and others, who have mandates ranging from agricultural training, poverty alleviation, biodiversity, and water conservation through to health, yet for different reasons have all found agroecology a critical component to realizing these mandates and notably building farmers resilience to adapt to climate change. It is against this context that two of these organizations working in partnership to promote agroecology among smallholder farmers in this area, collaborated to develop this chapter with the aim of sharing the findings of an evaluation conducted to understand the participating smallholder farmers' experiences of agroecology as both a livelihood option and a strategy for climate change adaptation. 


\section{Background Information}

Kruger to Canyons Biosphere Region encompasses parts of the Limpopo and Mpumalanga provinces, as well as three southern African biomes: grasslands, Afro-montane forests, and the savannah of the lowveld. And as shown in Fig. 1 below, the region borders with the vast Greater Kruger National Park, which is home to a diversity of flora and fauna. The Kruger to Canyons region also include much of both the upper and lower sub-catchment areas of the Olifants river. Major land-use practices in this region include conservation nature reserves areas, mining (gold, phosphate, copper), exotic plantations, and the extensive nonorganic cultivation of subtropical fruits and vegetables (mainly for export) and to a lesser extent peasant farming.

Perhaps the most important contextual history of this area, when considering the development of smallholder agriculture in post-apartheid South Africa, is the remnants of the former apartheid homelands or bantustans. These were areas the apartheid government set aside for African indigenous people to live after they were forcibly removed from urban areas. It was thus the mechanism with which the government realized segregation, but with which they also successfully created labor reservoirs for the mines and other South Africa industries active at the time. It is essential to take into consideration that although the apartheid government

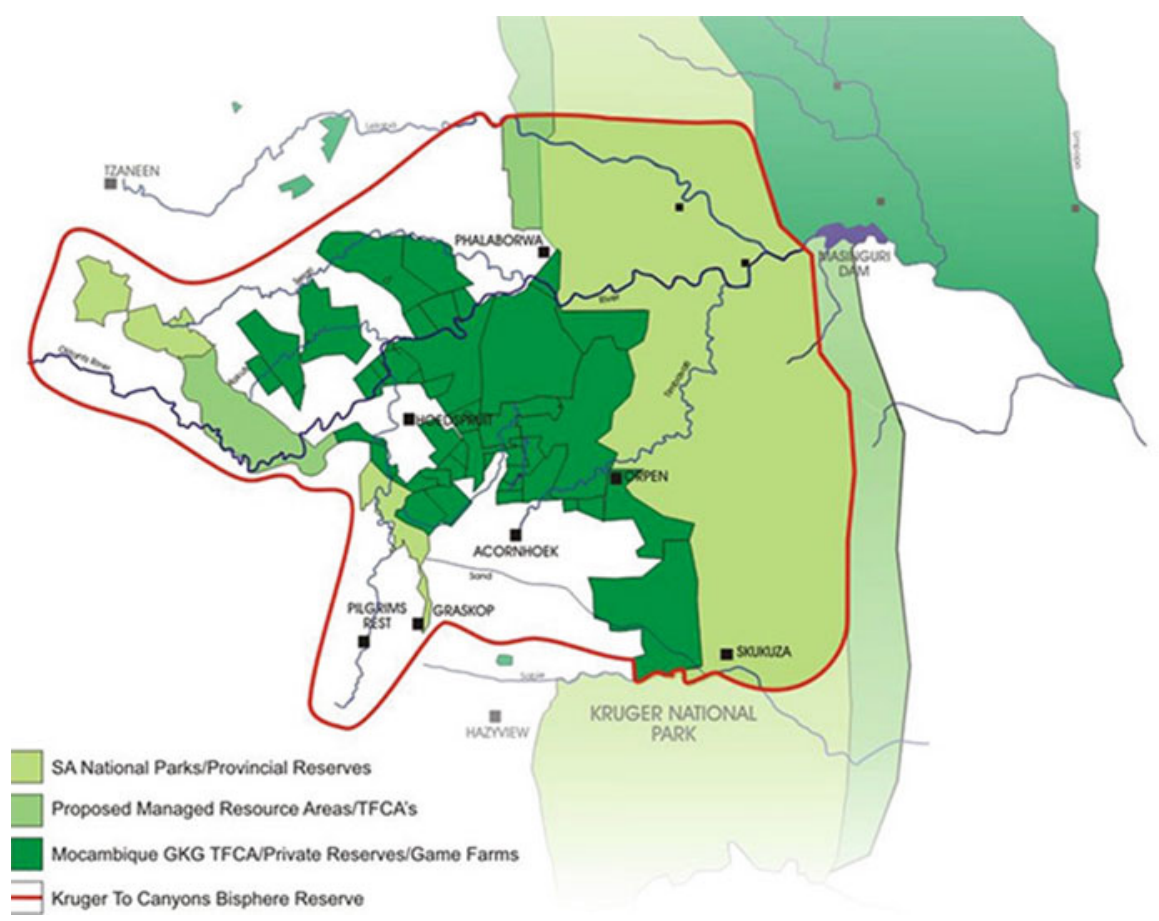

Fig. 1 Map of Kruger to Canyon landscape (AWARD 2016) 
intended for these areas to eventually become independent, they were not developed and relied entirely on the larger South African economy.

Vibert (2018) wrote a poignant piece about the effects of forceful removals during apartheid, which displaced people and gathered them in the former homelands. She writes specifically about one homeland that was partly located within the current biosphere, named Gazankulu. It "was envisioned as a rural enclave for women, children, and elderly people of Tsonga ethnicity - their men were the labour force in the mines and cities. This rural-urban binary is misleading: people and resources circulated among these spaces, within and in infraction of the strict spatial regulations of apartheid. Yet rural space was, under apartheid, a space apart" (Vibert 2018). Vibert writes how women recall arriving in this new space where very little preparations had been made for their arrival, finding it inhospitable. They built houses during the day and cooked at night to start a new life. They did not have enough allocated space to grow crops such as sorghum, which they had grown before.

\begin{abstract}
...We can't forget sorghum,' the indigenous grain they no longer have space or labour to grow. Mamayila says it's 'very painful [va va ngopfu] to remember the way we were situated. It was so nice. You had enough land to have your garden, donkeys, cattle kraal, one side for goats, one side for pigs.' Today we have 'maybe a cattle-kraal size' says Sara. (Vibert 2018)
\end{abstract}

Since the end of apartheid, not enough has been done to address the social complexities and trauma of the forceful removals or the underdevelopment of these former homelands, resulting among other social challenges, in millions of unemployed people. Given the legacy of Apartheid's forced removals, villages in Gazankulu are densely populated (Wright et al. 2013). And overutilization of natural resources combined with a lack of proper management of these resources has led to soil erosion and a loss of soil moisture and soil nutrients. These factors, together with low rainfall and poor soils in some areas, have affected smallholder farmer's capacity to produce enough food (AWARD 2016) and with climate change, their vulnerabilities are likely to increase.

Therefore, the work being done by the two development organizations is implemented within this context where historical segregation and limited formal development have left millions of people heavily dependent of agriculture and social grants as livelihoods options.

\title{
The Partnership
}

One of the two development organization is registered as a private company but operates as a social enterprise and training center in the Hoedspruit region. Its social development activities include a high school bursary program, and the training on agroecology, which is of interest to this chapter. The course is meant to equip smallholder farmers with skills and knowledge needed to practice agroecology as a form entrepreneurship along the organic food value chain. 


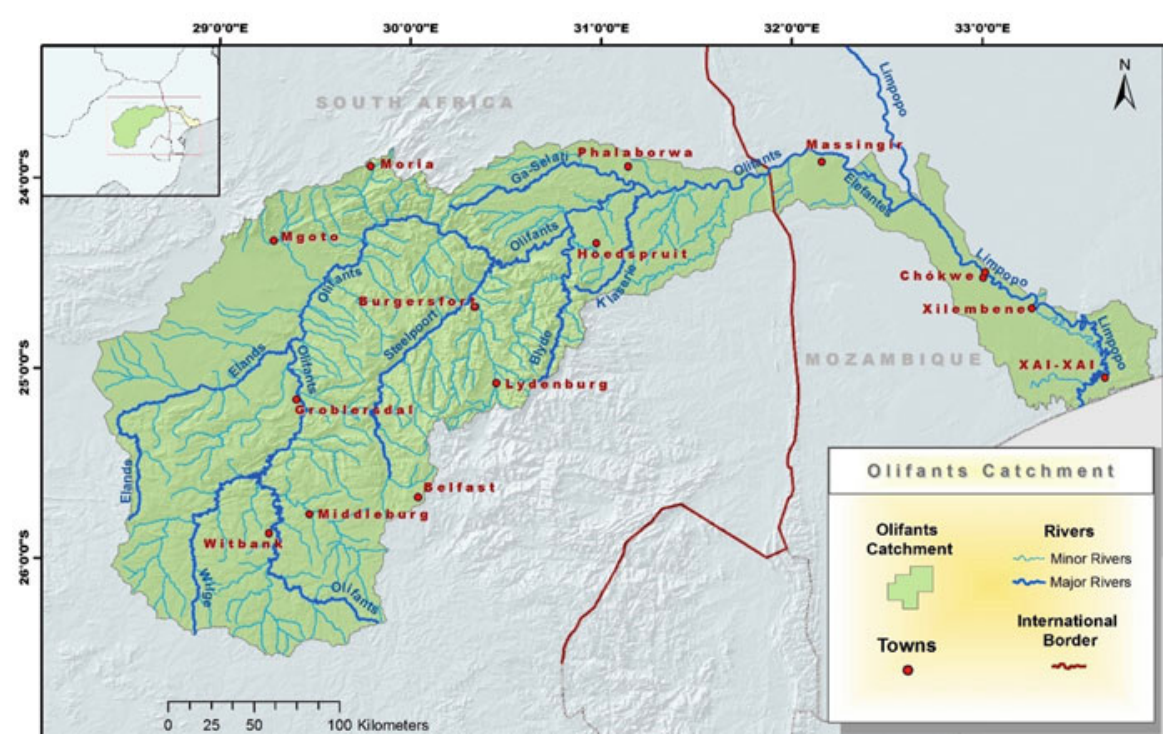

Fig. 2 Map of the Olifants river sub-catchment in which agroecology projects are being implemented (AWARD 2016)

The other organization is a nonprofit organization specializing in multidisciplinary, participatory, research-based project implementation aimed at addressing issues of environmental sustainability, inequity, and poverty, in particular relating to water conservation and management in the face of climate change. This organization's main geographical area of focus, although not exclusively limited to, is in the areas lying within the lower and upper catchment of the Olifants river - a major tributary of the Limpopo river, which is an international watercourse shared between South Africa and Mozambique. Figure 2 below is a map showing the entire Olifants river catchment.

\section{Changes in Climate}

Also, of interest in this chapter is how climate change is being experienced in southern Africa and how this will impact on agriculture. A recent piece in the Farmer's Weekly by Lindie Botha, drawing on the opinion of Prof. Francois Engelbrecht, chief researcher for climate studies, modelling, and environmental health at the Council for Scientific and Industrial Research (CSIR), states that "the average temperature increase in southern Africa due to climate change, is taking place at twice the global rate. The resulting lower rainfall figures and increase in the number of heatwaves will see agricultural landscapes shifting and veld fires growing in frequency. All of this will demand careful planning" and a type of agriculture that is climate smart (Botha 2019). She writes that the Department of Science and 
Technology launched the South African Risk and Vulnerability Atlas (SARVA) in response to the changing climates observed in the last few decades. SARVA published in 2018 that rural areas in South Africa are particularly vulnerable to climate change due to its dependence on water and agriculture.

It is against this background that the two partner organizations have, over the course of the partnership, trained and supported a total of 300 smallholder farmers to implement agroecology. And the need to learn more about how the target smallholder farmers are experiencing their implementation of agroecology is what motivate the evaluation, whose findings are discussed in this chapter

\section{Questions Investigated}

In order to gain an in-depth understanding of the farmers' experiences of adopting and implementing agroecology, the project evaluation against which this chapter is developed explored the following questions:

1. Why do smallholder farmers adopt an agroecological approach to farming?

2. Is adoption of agroecology as strategy for adaptation linked to farmers' awareness of climate change itself?

Exploring these evaluative questions was done in order to confirm if the agroecological approach is indeed the most effective way to not only meet organizational goals but to enhance the building of smallholder farmers' resilience to adapt to climate change. The answers to the questions of this evaluation are thus the basis for discussions presented in this chapter, the ultimate aim being to improve the way community development organizations work with and support smallholder farmers in South Africa and beyond.

The evaluation was conducted using a qualitative interpretive research approach. The decision to use a qualitative methodology was in sync with the nature of the evaluative questions that the two organizations sought to answer and also the ontological world views of what constitute reality held by the researchers (Creswell 2009; Niewenhuis 2007). Ontology, as defined by Niewenhuis (2007), refers to how one perceives reality or think of that which can be known. Similarly, Patton (2002, 2014) argued that ontology is concerned about the constitution of reality, in the case of this study, "farmers views and experiences of agroecology," and what we are able to know about it. Creswell (2009) also pointed out that ontological world views often shape the orientation and design of the evaluation methodology preferred. Hence the qualitative interpretive paradigm within which this evaluation was conducted, and the case study method used together with the data collection and analysis techniques all reflects the ontological viewpoint of knowledge as socially constructed (Denzin and Lincoln 2011; Maxwell 2010; Yin 2013). An evaluation methodology that does not only focus on the numbers of farmers trained and now then practicing agroecology was needed. Therefore, knowledge interest that required much more than just statistics for donor reporting determined the use of qualitative methodologies. And a 
qualitative approach allowed the evaluators to generate more insights into farmers experiences illuminating light on some of the grey areas where future programming needed to resolve in order to achieve not only more but sustainable impact, working with smallholder farmers in Limpopo to adapt to climate change.

\section{Using the Case Study Evaluation Method}

According to Harrison et al. (2017), case study research has grown in reputation as an effective means to explore and understand complex issues in real-world settings. It has been widely used across several disciplines, particularly the social sciences, education, business, law, and health, to address a wide range of research questions.

The case study method used in this evaluation allowed for a closer examination and analysis of each participating smallholder agroecology farmer in real-life contexts (Harrison et al. 2017). It also allowed the evaluators an opportunity to select information rich participants or cases (Flyvbjerg 2006, 2011) making it possible to generate enough data and in-depth insights into how agroecology is being experienced by and changing the lives of smallholder farmers. It also allowed them to probe in detail the extent to which farmers understand the connection between adopting agroecology and building their resilience to climate change.

Fifteen carefully selected cases of smallholder farmer households drawn from 300 farmers trained and being supported to implement agroecology. These households were purposively selected on the basis of having received training and actively implementing agroecological practices. Purposive sampling meant that the researchers had to pick on the most productive sample (smallholder farmers) that could provide adequate data to answer the research questions (Marshall 1996; Flyvbjerg 2006, 2011). It also allowed for the selection of what Yin (2014) referred to as data rich participants. And because this was not a comparative analytical evaluation, selecting those data-rich cases made much epistemological sense.

As represented in Table 1, the farmers involved in the evaluation included those that had been trained through 17 Shaft Training in 2015 and 2016 and those trained by Hoedspruit Hub in 2016 and 2017.

Evaluation information was collected using semi-structured interviews integrated with narrative enquiry and field observation. Yin (2014) argued that semi-structured interviews allow a researcher greater freedom to pursue unexpected, but interesting and relevant comments to a greater depth. Instead of a scripted list of questions, the researcher has a good idea of the questions she would like to ask, and perhaps even an interview guide, but may ask the questions in a way that fit the context of the emerging conversation between researcher and participant smallholder farmer (Yin 2014; Creswell 2009). Also important for a qualitative evaluation such as this one the use of semi-structured interviews allowed the farmers to answer questions in their own words, potentially adding details to the data that might have been missed otherwise (Yin 2011). The interview guide used to collect demographic information relating on participants profiles also provided a way of generating quantitative data 
Table 1 The smallholder farmers participating in the evaluation and their training

\begin{tabular}{l|l}
\hline Code name & Training received \\
\hline 1 & Leadership in Agroecology \\
\hline 2 & 17 Shaft Training (2016) \\
\hline 3 & Organic Mango Production \\
\hline 5 & 17 Shaft Training (2015) \\
\hline 6 & Organic Mango Production \\
\hline 7 & Herb Gardening \\
\hline 9 & Leadership in Agroecology \\
\hline 10 & Herb Gardening \\
\hline 11 & 17 Shaft Training (2016) \\
\hline 12 & 17 Shaft Training (2015) \\
\hline 13 & Entrepreneurship in Agroecology (2016) \\
\hline 15 & 17 Shaft Training (2016) \\
\hline
\end{tabular}

on harvest and income trends being experienced by smallholder farmers implementing agroecology.

Information collection also entailed use of narrative enquiry where farmers were asked to tell their stories of change. Dyson and Genishi (1994) asserts that storytelling provides a useful theoretical lens through which to examine the ways in which individuals experience the world as illustrated through their own personal stories. Narrative inquiry helped the evaluators to capture the farmers' full experiences of their adoption and implementation of agroecological farming practices. Davis (2007) also argued that storytelling is a very useful way of collecting data especially from informants with low literacy levels such as the case with most of the farmers involved in this project evaluation. As such storytelling helped to make this project evaluation socially inclusive in orientation.

With the consent of participants, their stories and responses to interviews were audio recorded for data transcription and analysis. Some of the interviews were video recorded and footage stored for the future development of a short video film to support the sharing of the emerging findings of the project evaluation.

In order to deepen insights and triangulate information collected through the interviews (Shenton 2004), field observations were conducted and entailed visiting homesteads of all the 15 farmers to learn more about their agroecological practices and ascertain harvests being experienced. Photography was used to capture observations made during the field trips.

In total, 15 interviews were done, and visits to all the 15 farmers undertaken. The data generated was processed through transcribing, translation into English, making it ready for analysis

Information collected was subjected to initial analysis using Atlas Ti 7 to both locate and code the data (Friese 2014). Dohan and Sanchez-Jankowski (1998) 
argued that coding data with a well-designed computer program like Atlas Ti 7 can be very useful but not an end in itself. Analysis of data was thus continued using thematic data analysis where emerging themes relating to questions being pursued in the evaluation and discussed in this handbook chapter were identified and analyzed.

\section{Evaluation Findings}

\section{Farming Sites}

The 15 smallholder farmers who participated in this project evaluation were drawn from the villages as shown in the map below. All these villages are adjacent to the Kruger to Canyons Biosphere area and falls within Maruleng, Lepele Nkhumpi, and Elias Motshoaledi municipalities of Limpopo province. In terms of climate, these areas are generally quite dry with an annual rainfall of around $500 \mathrm{~mm} / \mathrm{year}$ concentrated in 4 months during the summer (AWARD 2016).

Farmers were selected from villages such as Sidawa, Zebedela, Turkey, and Mametja of Maruleng, and Motetema, Tarfelskop, Makweng, Dithabaneng, Makushoaneng, and Monsterlus of Carpricorn and Elias Motshoaledi (Fig. 3).

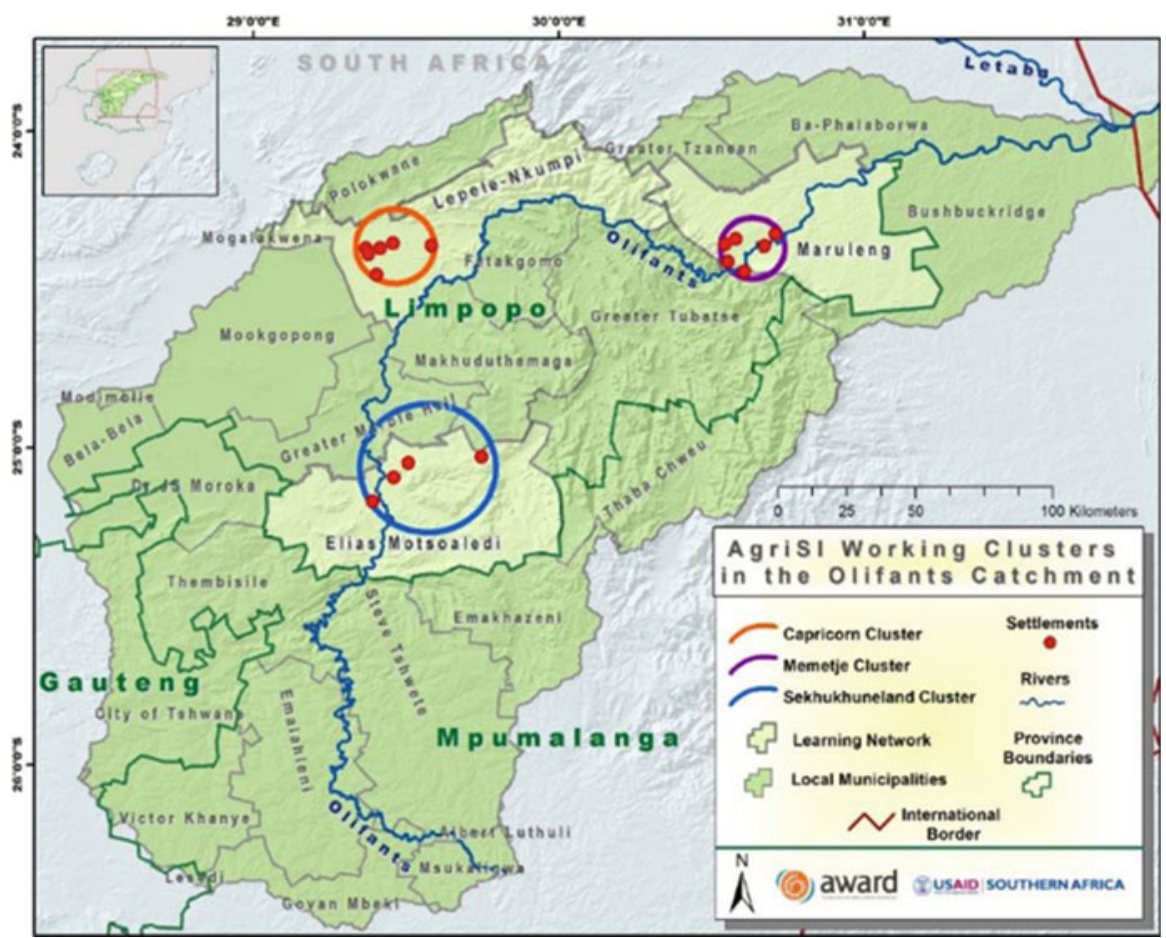

Fig. 3 Villages implementing agroecology (AWARD 2016) 


\section{Demographics}

Of the 15 farmers interviewed, 11 were female and 4 were male. Average age of the smallholder farmers interviewed was 45.3 , with the youngest being 20 years old. On average, each household size was reported as made up six family members.

The plot sizes for most farmers ranged from 0,002 ha (an area of $4 \mathrm{~m} \times 5 \mathrm{~m}$ ) being the smallest to the largest of $0,54 \mathrm{ha}$. Each farmer was producing a good mix of vegetables with limited fruit and herbs. Those farming herbs were benefiting from the market linkage support that Hoedspruit Hub was providing. Table 2 illustrates the above demographics of the farmers.

\section{Reasons for Adopting Agroecological Farming Practices}

The chapter confirms that most of the farmers interviewed has various reasons for practicing agroecology. These reasons ranged from the need to produce more food for household consumption, desire to generate income, and influence from neighbors to the farmers' realization of declining yields.

Asked to share his motivation for taking up and practicing agroecology one of the farmers was quoted saying:

Remember the first thing which is needed by the family before they do any job is food. So for me, I work for food first and then seek money elsewhere. (F2)

Similarly, the other farmer interviewed weighted in by pointing out that:

Table 2 Smallholder farmer demographics

\begin{tabular}{l|l|l|l|l|l}
\hline Code & Age & Gender & Size of family & Years farming & Production area (ha) \\
\hline 1 & 48 & Female & 3 & 6 & 0,540 \\
\hline 2 & 41 & Female & 6 & 2 & 0,035 \\
\hline 3 & 53 & Female & 4 & 1 & 0,534 \\
\hline 4 & 44 & Female & 5 & 26 & 0,500 \\
\hline 5 & 56 & Male & 4 & 1 & 0,003 \\
\hline 6 & 40 & Male & 5 & 10 & 0,500 \\
\hline 7 & 52 & Female & 5 & 2 & 0,002 \\
\hline 8 & 58 & Female & 3 & 2 & 0,250 \\
\hline 9 & 20 & Female & 5 & 0.2 & N.A. \\
\hline 10 & 59 & Female & 3 & 10 & N.A. \\
\hline 11 & 28 & Female & 2 & 2 & 0,200 \\
\hline 12 & 30 & Male & 5 & 3 & 0,420 \\
\hline 13 & 39 & Female & 3 & 7 & 0,200 \\
\hline 14 & 44 & Female & 6 & 3 & 0,500 \\
\hline 15 & 48 & Male & 2 & 4 & 0,032 \\
\hline Averages & 45,3 & & 4 & 5,6 & 0,28 \\
\hline
\end{tabular}


When I started implementing the permaculture (agroecology) ideas, I noticed that my vegetable production doubled, compared to the first yield where I had little knowledge. This method is cheap and sustainable long term. (F4)

Asked to explain why adopting agroecology and converting from the usual conventional farming, another farmer confidently said that:

I have a diversity of activities in order to produce a wide variety of results such as generating income, providing my family with meat and vegetables. (F7)

Two of the interviewed farmers were despite trained, however, not yet practicing agroecology. The two perceived agroecology as for mainly very small farmers, thus not very suitable for their scale of farming.

It became quite clear that the smallholder farmers interviewed were practicing agroecology because of different reasons. These as reflected above included the both the need to feed their families and earn income from selling the surplus backyard gardening produce. Producing more food to feed the family and income generation as, confirmed by responses from $66 \%(n=10)$ of farmers interviewed, emerged the top two reasons influencing adoption and practicing of agroecology. The desire to improve household income as a reason for practicing agroecology was made much more explicit by a farmer who shared her story as quoted below.

Life with my children and no support from their father was not a good life for me at all. I tried many things to improve the living conditions of my children. I received government benefit but it was not enough to send them to school, provide medical support and to buy the right food. One of the areas I got passionate about was farming, but I had no skills. But then I got training in agroecology and started from a small base growing a few vegetables and crops.... and now I earn more money and I am happy.... (F10)

The desire to produce food for the family, to share with neighbors, and sell the surplus to generate income is illustrated in Table 3.

Other influencing factors included realization that their soils are no longer producing as much as they used to, keeping up with the jones (learning from neighbors) and as well lack of employment opportunities especially among the youth in the lowveld. About 33\% $(\mathrm{n}=5)$ of active agroecological farmers were unemployed and many cited this as the original reason for starting their agroecological production units. For many farmers, continued unemployment meant no other option than to continue farming agroecologically. One farmer alluded to the medicinal value of herbs as the reasons for his interest in doing agroecology. Access to market and increasing demand for organic vegetables by local lodges were also mentioned as factors shaping the way agroecology was being adopted and implemented. Also, very interesting is that a few farmers thought that agroecology is easier and cheaper to do as it does not require heavy use of chemicals and fertilizers. Ecological reasons for implementing agroecological farming practices were also observed and some of the farmers talked of the need to improve soil health 
Table 3 Household consumption, sharing, and selling of agro-produce

\begin{tabular}{|c|c|c|c|c|}
\hline Code & Household use (\%) & Sharing (\%) & Selling (\%) & Income p.m. (rands) \\
\hline F1 & 54 & 22 & 24 & 900 \\
\hline $\mathrm{F} 2$ & 20 & 80 & 0 & 0 \\
\hline F3 & 20 & 0 & 80 & 600 \\
\hline $\mathrm{F} 4$ & 50 & 0 & 50 & 5000 \\
\hline F5 & 10 & 10 & 80 & 1200 \\
\hline F6 & 20 & 0 & 80 & 800 \\
\hline F7 & 20 & 40 & 40 & 200 \\
\hline F8 & 10 & 0 & 90 & 300 \\
\hline F9 & N.A. & N.A. & N.A. & 0 \\
\hline F10 & N.A. & N.A. & N.A. & 0 \\
\hline F11 & 100 & 0 & 0 & 0 \\
\hline F12 & 60 & 0 & 40 & 420 \\
\hline F13 & 40 & 5 & 55 & 5100 \\
\hline F14 & 90 & 5 & 5 & 120 \\
\hline F15 & 20 & 10 & 70 & 600 \\
\hline Avg & 33,77 & 16,88 & 49,33 & 1016,00 \\
\hline
\end{tabular}

and save water. Asked to explain why she adopted agroecology, one farmer felt agroecology enabled communities to live in harmony with nature, and she said that,

To me it would be beneficial if more people can farm agroecologically and if they can impart it to their children. People say they are going to pray for rain. We are not living harmoniously with nature, and not sending rain is nature's response. It's how nature talks

The desire to save water which was also linked to ecological reasons for taking up agroecology could be easily understood from the fact that most of the farmers in the area covered by this evaluation (lowveld of Limpopo) did not have reliable water supply and were actually buying water (Award 2016) to sustain their gardens. Water was therefore even without or before onset of climate change a scarce resource. Others talked of social motivations including that gardening kept them physically active and healthy, reducing stress, and keeping them out of poverty and criminal activities.

The observations made above were also reported by similar research studies. Studies done by Nilesa and Mueller (2016) revealed that farmers change their agricultural behaviors not only because of the changes in climatic conditions. The evaluation findings revealed that factors such as the inherent desire to sustain food security and the changes in the wider environment, e.g., changes in soil fertility and productivity levels, contributed to the changes in agricultural practices adopted by farmers. Scholars such as Toffolini et al. (2018) also revealed that the evolution of farmers' practices towards agroecology is mainly influenced by agronomist factors to increase food production. In a similar sense, Hubert (2012) also observed that agroecology has, in various countries, been considered a viable option for achieving 
sustainable food production systems. Accordingly, Altieri (1999) claimed that the agroecological approach provides an alternate path to increasing crop production because of its reliance on local farming knowledge and technologies suited to different and marginal climatic conditions such as those of Limpopo.

\section{The Connection Between Agroecology and Climate Change}

Out of the 15 farmers interviewed in this project review, only one $(n=1)$ of them made an explicit reference to climate change. This is a very interesting observation but one that is unusual. Such an observation can be understood from what other studies has revealed. Nilesa and Mueller (2016) pointed out that they are unaware of any studies that have examined the extent to which farmers' perception of climate change directly explains their changes in farming practices. Whyte (2014) also observed that even though the broad issue of adaptation to environmental change is not new for many indigenous peoples, it is something done out of survival instincts rather than any significant levels of climate change awareness. Closely related, Mugambiwa (2018) concluded that subsistence farmers have always adopted adaptive strategies to changes such declining crop yields. In his study, he concluded that changes in farming practices such as a shift from maize to traditional millet and sorghum that farmers in Mutoko, a district in Zimbabwe, adopted were triggered by the desire to preserve local indigenous knowledges and cultures rather than the changing climatic conditions. However, it can be argued that this change and adoption of indigenous knowledge practices as acknowledged by Waha et al. (2013) to respond to frequent droughts, scarcity of rain, and decreased crop yields is by default a strategy for adapting to climate change.

Other studies done by Arbuckle et al. (2013) and Niles et al. (2015) to investigate farmers' perceptions of climate change, its risks, and potential to influence adoption of adaptation and mitigation behaviors also confirmed that farmers relate more to weather than climate change. This observation is also reflected in what one farmer who made reference to climate change was quoted saying,

\footnotetext{
Then I ask myself, isn't it important to know, what is hindering rain from coming? So, all these practices we are doing, it's hindering rain from coming, by contributing to climate change. We can pray and pray and pray, but if we don't change our thinking, decolonise our minds, rain will not come. We can expect drought
}

Farmers are therefore arguably more affected by weather-related losses than climate change per se. Thangata et al. (2002) argued that the decisions made by smallholder farmers to adopt agroecological practices, e.g., agroforestry, in the context of Zambia reflected the farmers' perceptions of worst-case weather changes such as delayed rainfall or droughts. And thus, if they were asked about how weather determines their farming practices, a good number of the farmers involved in this evaluation could have provided more explicit answers. This finding denotes the need to appreciate that for most farmers the adoption of agroecology is, at experience 
level, motivated more by other factors than solely climate change (Palm et al. 2010; Beddington et al. 2011; Nyanga et al. 2011).

While agroecology has been widely associated with strengthening the resilience of farmers and rural communities (Niles et al. 2015), evidence to support that adoption of agroecological practices is a direct result of the farmer's awareness of climate change remains anecdotal. Nyanga et al. (2011), in a study done in Zambia, also reported of a positive correlation between perception of increased droughts and adoption of conservation agricultural practices such as agroecology but no correlation between farmer' attitudes towards climate change itself. The increased interest in agroecology has also been not only linked to climate change but other narratives such as the green revolution. Hence the tendency to give function to agroecology and all its associated soil, water, and biodiversity conservation technologies, as a strategy for climate change adaptation, can only be referred to as of zero interest from the perspective of farmers. Other scholars have further critiqued the way agroecology has now been hijacked by the politics of the day and repackaged as climate smart agriculture. The implication of the observation made here is that it is just as important to know the priorities of the farmer implementing agroecology practice than to present it as solely a climate change adaptation measure.

\section{Conclusion}

While the work done by the two development organizations who commissioned the writing of this chapter is aimed at building resilience for climate change adaptation, it is important to note that farmers' decisions to adopt agroecology is influenced by many other factors. This observation gives added value to the need for additional interventions such as the dialogues for climate change literacy and adaptation (DICLAD) which can improve farmers' levels of knowledge and awareness of climate change, and how this relates to adopted agroecological practices being implemented.

In general, the findings discussed in this chapter also calls for a redesign of contemporary farmer extension support services. There is need to adopt approaches that not only empowers farmers with basic knowledge of climate change science but also recognize that agroecological practices and technologies have a history that is tied to a range of evolving farmer's priorities. Working with farmers and getting them to a level of consciousness that recognizes the value of their indigenous agroecological knowledges and systems for more than just climate change adaptation is what must be pursued. Therefore, advancing the climate change adaptation dimension of agroecology at the expense of the other equally important roles and values is not only reductionist but problematic. 


\section{References}

Altieri MA (1995) Agroecology: the science of sustainable agriculture. Westview Press, Boulder

Altieri MA (1999) Applying agroecology to enhance the productivity of peasant farming systems in Latin America. Environ Dev Sustain 1:197-217

Arbuckle et al (2013) Climate change beliefs, concerns, and attitudes toward adaptation and mitigation among farmers in the Midwestern United States. Clim Change 117:943-950

AWARD (2016) Grain-SA smallholder farmer innovation Programme, annual report (2015-2016). Limpopo, South Africa

Beddington et al (2011) Achieving food security in the face of climate change: summary for policy makers from the commission on sustainable agriculture and climate change. In CGIAR Research Program on Climate Change. Agriculture and Food Security (CCAFS), Copenhagen. Available on http://www.ccafs.cgiar.org/commission. Accessed 10 June 2020

Botha L (2019) Climate change: it's happening faster than you think. Farmers Weekly, 7 January. Available: https://www.farmersweekly.co.za/agri-technology/farming-for-tomorrow/climatechange-happening-faster-think/. Accessed 4 Jan 2020

Creswell JW (2009) Research design. Qualitative, quantitative and mixed methods approaches, 3rd edn. SAGE, London

Creswell JW (2013) Qualitative inquiry and research design: choosing among five approaches. SAGE, Thousand Oaks

Creswell JW, Plano CV (2007) Designing and conducting mixed methods research. SAGE, Thousand Oaks

Davies MB (2007) Doing a successful research project, using qualitative or quantitative methods. Palgrave Macmillan, New York

Davis P (2007) Storytelling as a democratic approach to data collection: interviewing children about reading. Educ Res 49(2):169-184

Denzin NK, Lincoln YS (2011) Introduction: the discipline and practice of qualitative research. In: Denzin NK, Lincoln YS (eds) The Sage handbook of qualitative research, 4th edn. SAGE, Thousand Oaks, pp 1-20

Dohan M, Sanchez-J M (1998) Using computers to analyse ethnographic field data: theory and practical considerations. Annu Rev Sociol 24:477-498

Dyson AH, Genishi C (1994) The Need for Story: Cultural Diversity in Classroom and Community. National Council of Teachers of English, 1111 W. Kenyon Rd., Urbana, IL 61801-1096

Flyvbjerg B (2006) Qualitative inquiry: five misunderstandings about case-study research. SAGE, London

Flyvbjerg B (2011) Case study. In: Denzin NK, Lincoln YS (eds) The Sage handbook of qualitative research, 4th edn. SAGE, Thousand Oaks, pp 301-316

Friese S (2014) Qualitative data analysis with ATLAS.ti, 2nd edn. SAGE, London

Gillham B (2005) Cases study research method. Continuum, New York

Harrison H, Birks M, Franklin R, Mills J (2017) Case study research: foundations and methodological orientations. Forum Qual Soc Res 18(1):Art 19. http://nbn-resolving.de/urn:nbn: de:0114-fqs1701195. Accessed 19 May 2020

Hubert C (2012) Agrarian dynamics and population growth in Burundi: Agroecology before its time. core.ac.uk/display/87834265. Accessed 10 June 2019

Marshall MN (1996) Sampling for Qualitative Research. Family Practice 13:522-525. https://doi. org/10.1093/fampra/13.6.522. Accessed 14 Aug 2019

Maxwell JA (2010) Qualitative Research Design: An Interactive Approach (Applied Social Research Methods) 3rd Edition. Sage

Mugambiwa SS (2018) Adaptation measures to sustain indigenous practices and the use of indigenous knowledge systems to adapt to climate change in Mutoko rural district of Zimbabwe. Unpublished $\mathrm{PhD}$ study

Muhammad A, Janpeter S, Jürgen S, Farhad Z (2016) Climate change vulnerability, adaptation and risk perceptions at farm level in Punjab, Pakistan. Sci Total Environ 547:447-460 
Niewenhuis J (2007) Qualitative research design and data gathering techniques. In: Maree K (ed) First steps in research. Van Schaik Publishers, Pretoria

Niles MT, Lubell M, Brown M (2015) How limiting factors drive agricultural adaptation to climate change agriculture. Ecosystem Environ 200:178-185

Nilesa MT, Mueller ND (2016) Farmer perceptions of climate change: associations with observed temperature and precipitation trends, irrigation, and climate beliefs. Glob Environ Chang 39:133-142

Nyanga P, Johnsen F, Kalinda T (2011) Smallholder 'farmers' perceptions of climate change and conservation agriculture: evidence from Zambia. J Sustain Dev 4(4):73-85

Palm C et al (2010) Identifying potential synergies and trade-offs for meeting food security and climate change objectives in sub-Saharan Africa. Proc Natl Acad Sci 107(46):19661-19666

Patton MQ (2002) Qualitative research and evaluation methods, 3rd edn. SAGE, London

Patton MQ (2014) Qualitative research and evaluation methods. Integrating theory and practice. SAGE, London

Patton MQ (2017) Facilitating evaluation. Principles in practice. SAGE, London

Prokopy et al (2015) Farmers and climate change: a cross-national comparison of beliefs and risk perceptions in high-income countries. Environ Manag 56:492-504

Shenton AK (2004) Strategies for ensuring trustworthiness in qualitative research projects. In Education for Information. London: IOS Press

Terre Blanche M, Kelly K (1999) Interpretive methods. In: Terre Blanche M, Durrheim K (eds) Research in practice. Applied methods for the social sciences. UCT, Cape Town

Thangata P, Hildebrand P, Gladwin C (2002) Modelling agroforestry adoption and household decision making in Malawi. Afr Stud Q 6(1-2):249-268

Thomas DR (2006) A general inductive approach for analyzing qualitative evaluation data. Am J Eval 27(2):237-246. https://doi.org/10.1177/1098214005283748. Accessed 12 May 2020

Toffolini Q et al (2018) Agroecology as farmers' situated ways of acting: a conceptual framework. Agroecol Sustain Food Syst

Vibert E (2018) Healing in the soil. Womensfarm.org. https://www.womensfarm.org/hleketanigarden/healing-in-the-soil/. Accessed 14 Jan 2019

Waha K, Bondeau A, Müller C (2013) Adaptation to climate change through the choice of cropping system and sowing date in sub-Saharan Africa. Glob Environ Chang 23(1):130-143

Whyte KP (2014) A concern about shifting interactions between indigenous and nonindigenous parties in U.S. climate adaptation contexts. Interdiscip Environ Rev, Vol. X, No. Y, XXX

Wright et al (2013) Lower Olifants community health: risks and opportunities. Project report

Yin R (2013) Case Study Research: Design and Methods. SAGE Publications

Yin RK (2009) Case study research: design and methods. SAGE, Thousand Oaks

Yin RK (2011) Qualitative research from start to finish. Guilford Press, New York

Yin RK (2014) Case study research: design and methods. SAGE, Los Angeles

Open Access This chapter is licensed under the terms of the Creative Commons Attribution 4.0 International License (http://creativecommons.org/licenses/by/4.0/), which permits use, sharing, adaptation, distribution and reproduction in any medium or format, as long as you give appropriate credit to the original author(s) and the source, provide a link to the Creative Commons license and indicate if changes were made.

The images or other third party material in this chapter are included in the chapter's Creative Commons license, unless indicated otherwise in a credit line to the material. If material is not included in the chapter's Creative Commons license and your intended use is not permitted by statutory regulation or exceeds the permitted use, you will need to obtain permission directly from the copyright holder. 